University of Nebraska - Lincoln

DigitalCommons@University of Nebraska - Lincoln

Roman L. Hruska U.S. Meat Animal Research

U.S. Department of Agriculture: Agricultural Center

Research Service, Lincoln, Nebraska

2011

\title{
Assessment of pubertal development of boars derived from ultrasonographic determination of testicular diameter
}

\author{
J.J. Ford \\ USDA, ARS, U.S. Meat Animal Research Center, Reproduction Research Unit, Clay Center, Nebraska \\ T.H. Wise \\ USDA, ARS, U.S. Meat Animal Research Center, Reproduction Research Unit, Clay Center, Nebraska
}

Follow this and additional works at: https://digitalcommons.unl.edu/hruskareports

Part of the Animal Sciences Commons

Ford, J.J. and Wise, T.H., "Assessment of pubertal development of boars derived from ultrasonographic determination of testicular diameter" (2011). Roman L. Hruska U.S. Meat Animal Research Center. 164. https://digitalcommons.unl.edu/hruskareports/164

This Article is brought to you for free and open access by the U.S. Department of Agriculture: Agricultural Research Service, Lincoln, Nebraska at DigitalCommons@University of Nebraska - Lincoln. It has been accepted for inclusion in Roman L. Hruska U.S. Meat Animal Research Center by an authorized administrator of DigitalCommons@University of Nebraska - Lincoln. 


\title{
Assessment of pubertal development of boars derived from ultrasonographic determination of testicular diameter§
}

\author{
J.J. Ford ${ }^{\mathrm{a}, *}$, T.H. Wise ${ }^{\mathrm{a}}$ \\ ${ }^{\text {a } U S D A, ~ A R S, ~ U . S . ~ M e a t ~ A n i m a l ~ R e s e a r c h ~ C e n t e r, ~ R e p r o d u c t i o n ~ R e s e a r c h ~ U n i t, ~ C l a y ~ C e n t e r, ~ N e b r a s k a ~ 68933, ~ U S A ~}$
}

Received 17 May 2010; received in revised form 5 August 2010; accepted 17 August 2010

\begin{abstract}
At the onset of puberty, seminiferous tubules rapidly increase in diameter, thereby occupying a greater proportion of the testis, resulting in a rapid increase in testicular size. The objective of the current studies was to evaluate ultrasonography for assessing testicular diameter, as a basis for ranking boars relative to their extent of pubertal development. In the initial study, prior to castration at 4, 5, 6, or 7 mo of age, testicular length and diameter were assessed by ultrasonography in 160 anesthetized boars. After castration, testes were weighed. Mean diameter of seminiferous tubules and percentage of the testis occupied by tubules were determined by histological evaluations of all testes. Testicular volume was calculated from length and diameter and was correlated with testicular weight $(\mathrm{P}<0.001 ; \mathrm{r} \geqq 0.78)$ within each of the four age groups. At 4 and 5 mo of age, testicular diameter correlated positively $(\mathrm{P}<0.001)$ with diameter of seminiferous tubules; this relationship was not significant at older ages. In two subsequent studies, testicular diameter determined ultrasonographically in conscious boars was highly correlated $(r>0.8)$ when assessed twice on the same day, or when diameter of the right was compared with diameter of the left testis. Similarly, testicular diameter obtained initially at $92 \mathrm{~d}$ of age correlated positively $(\mathrm{P}<0.001)$ with the diameter observed at older ages, but the magnitude of the relationship decreased as time between evaluations increased. These findings supported ultrasonographic determination of testicular diameter during early pubertal development, as a means to rank boars of similar chronological age for extent of pubertal development.
\end{abstract}

(C) 2011 Elsevier Inc. All rights reserved.

Keywords: Boar; Puberty; Testis; Seminiferous tubule; Ultrasonography

\section{Introduction}

Onset of pubertal development in mammalian males involves rapid expansion of seminiferous tubules, accompanied with markedly increasing testicular size $[1,2]$. Within the testis of pubertal males, proliferation of Sertoli cells ceases in association with formation of

\footnotetext{
${ }^{\S}$ Mention of trade names or commercial products in this article is solely for the purpose of providing specific information and does not imply recommendation or endorsement by the U.S. Department of Agriculture.

* Corresponding author: Tel.: 1402762 4184; fax 14027623682.

E-mail address: joe.ford@ars.usda.gov (J. Ford).
}

the blood-testis barrier; luminal development occurs within the seminiferous tubules, and secretion of fluids into tubular lumens increases. These changes are followed by release of mature spermatids into the lumen and their movement into the mediastinum. Evaluation of scrotal circumference in bulls and rams with their pendulous scrotum offers an effective method to estimate testicular development in pubertal males [3-6]. However, assessment of scrotal circumference in pubertal boars is not practiced routinely, due to their nonpendulous scrotum with its broader attachment. No reports were identified that comprehensively examined the association of development of 
seminiferous tubules in pubertal boars with the diameter of their testes.

Ultrasonography has been used to estimate testicular dimensions in many species, including boars [7,8], thereby providing potential to develop a means to estimate stage of pubertal development in boars. For maternal lines, younger pubertal age is desirable, whereas in terminal sire lines, sexual maturity at older ages has an advantage of delaying onset of sexual behavior during rearing. The objectives of the first study were to: 1) characterize testicular development of boars by evaluating testicular weight and morphological changes at defined ages throughout pubertal development; 2) estimate correlations of mean diameter of seminiferous tubules with testicular diameter determined by ultrasonography; and 3) estimate the correlations of mean diameter of seminiferous tubules with testicular weight. The objective of the second and third studies was to use ultrasonography to estimate the relationships within boars of testicular diameter at successive ages.

\section{Materials and methods}

\subsection{Animals, management, and sample collection}

Boars were a four-breed composite [9] maintained by inter se mating and reared at the U.S. Meat Animal Research Center using standard production and experimental practices, in accordance with the Guide for the Care and Use of Agricultural Animals in Agricultural Research and Teaching [10]. All boars were weaned at 15 to $21 \mathrm{~d}$ of age, reared in confinement buildings, and fed standard diets formulated to meet NRC requirements varying with increasing age to accommodate changing nutritional needs. Water was available $a d$ libitum. Boars in the first $(\mathrm{N}=160)$ and second study $(\mathrm{N}=25)$ were progeny of 12 sires. Boars in the third study $(\mathrm{N}=63)$ were progeny of 12 different sires. Body weights were obtained at birth, weaning, and at 2 and 5.5 mo of age.

\subsection{Experiment 1-Testicular traits during pubertal development}

In the first study, the right testis of each boar was removed at $3,4,5,6,7$ or 10 mo of age, to evaluate weight and morphological changes during pubertal development; the number of boars per each age was 24 , $24,21,33,24$, and 34, respectively. Space restrictions and requirements of other experiments did not allow age at unilateral castration to be randomized across the three farrowing seasons. Boars in Season 1 (May farrowing) were unilaterally castrated at 6 mo of age; boars in Season 2 (July farrowing) were unilaterally castrated at 4, 5, or 7 mo of age, and boars in Season 3 (January farrowing) were unilaterally castrated at 3 mo of age, or were bilaterally castrated at 10 mo of age. Boars were given $2.5 \mathrm{mg} / \mathrm{kg}$ of xylazine (RX Veterinary Products, Westlake, TX, USA) im, 15 to $20 \mathrm{~min}$ before they were given thiopental sodium (Hospiara, Inc., Lake Forest, IL, USA) iv, followed with closed circuit anesthesia of isoflurane (Halcarbon Laboratories, North Augusta, SC, USA) and oxygen. The scrotal area was cleaned thoroughly with surgical soap, and then $70 \%$ ethanol. After expulsion of the testis, the spermatic cord was ligated and the testis removed. The left testis of these boars was removed at 10 mo of age using the protocol described above. Likewise, 34 additional boars were bilaterally castrated at 10 mo of age to define testicular weight at this older postpubertal age.

Boars that were unilaterally castrated at 4,5 , or $7 \mathrm{mo}$ of age (Season 2) and boars unilaterally castrated at 3 mo, or bilaterally castrated at 10 mo of age (Season 3) were assigned at random, stratified within sire, to age of castration using all vigorous boars within a litter. In contrast, boars that were unilaterally castrated at 6 mo of age (Season 1) were the larger boars within a litter and were selected prior to weaning only from large litters balanced within sire.

Before hemicastration at 4, 5, 6, or 7 mo of age, length and width of the right testis of anesthetized boars were determined by B-mode ultrasonography (Model SSD-500V with UST-5011-3.5 linear transducer and standoff formed to fit curvature of testes; Aloka, Wallingford, CT, USA). Water-soluble gel (LiquaSonic Ultrasound Gel; Chester Labs Inc, Cincinnati, OH, USA) was applied to the transducer and to the boar's scrotum before acquiring images, as described previously [8]. Ultrasonographic images were captured when there was clear visibility of the mediastinum and the tunica albuginea on both sides of the testis. At each age, volume was calculated using the length and diameter estimated by ultrasonography. The right testis was removed at the specified ages of hemicastration.

After castration at all ages, testes were trimmed, weighed, and split longitudinally. Two aliquots of tissue, $<1 \mathrm{~cm}^{3}$, were placed immediately into $10 \%$ formalin (neutral, phosphate buffered; Polysciences, Inc., Warrington, PA, USA) for approximately $5 \mathrm{~h}$ with gentle agitation followed by placement into fresh fixative with additional agitation for approximately $22 \mathrm{~h}$. Thereafter, blocks of tissue were dehydrated with in- 
creasing concentrations of ethanol and imbedded in paraffin $[11,12]$.

Proportion of testis occupied by seminiferous tubules and diameter of seminiferous tubules were determined for each boar on $5 \mu \mathrm{m}$ sections that were deparaffinized and stained with hematoxylin [12]. The morphology of four random fields from one section of each aliquot of tissue per boar was evaluated via brightfield microscopy using computerized morphometric planimetry (Bioquant Nova Advanced Image Analysis 2000; R\&M Biometrics, Inc., Nashville, TN, USA [12]). Weight of parenchyma was estimated by multiplying testicular weight by 0.91 to adjust for weight of the tunica albuginea [13].

\subsection{Experiments 2 and 3-Repeatability of testicular diameter at successive ages}

In the second and third studies, diameter of testes was estimated by ultrasonography at sequential ages while conscious boars were confined within a scale pen using a Model SSD-900V with UST-5524-7.5 linear transducer (Aloka). Water-soluble gel was applied to the transducer prior to monitoring and capture of the ultrasonographic image. The second study estimated testicular diameter at $114 \pm 0.6 \mathrm{~d}$ of age. Ten of these boars were re-evaluated a second time the same day, with knowledge of their first estimated diameter concealed from the evaluator. All boars were re-evaluated at $134 \pm 0.7 \mathrm{~d}$ of age and were castrated at $300 \mathrm{~d}$ of age. In the third study, diameters of the left and right testes were estimated at a mean age of $96 \pm 0.4 \mathrm{~d}$. Additional estimates of diameters of the left testis of these same boars were recorded at mean ages of $122 \pm$ $0.3,144 \pm 0.3$, and $164 \pm 0.3 \mathrm{~d}$.

\subsection{Statistical analyses}

Mixed Models procedures of SAS were used to evaluate season of rearing upon body weight at birth, weaning, 2 mo, and at 5.5 mo of age [14]. Body weight at each age was evaluated in a separate analysis, with season as the main effect, age on the day weight was recorded was a covariate, and sire was a random effect.

Statistical evaluation of changes in testicular traits were restricted to boars unilaterally castrated at 4, 5, or 7 mo of age (boars reared within a common season) using Mixed Models procedures, with age of castration as the main effect, birth weight as a covariate, and sire as a random effect. When the main effect was significant $(\mathrm{P}<0.05)$, means were compared with the PDIFF option.

Correlation coefficients ( $r$ ) among testicular traits within boars of a common age group were derived from linear regression procedures of SAS [15]. Data are presented as mean \pm SEM.

\section{Results}

\subsection{Experiment 1}

Weaning weight and 5.5 mo weight differed $(\mathrm{P}<$ 0.05 ) across the three seasons of rearing (Table 1). The percentage of the testis occupied by seminiferous tubules increased $(\mathrm{P}<0.01)$ after 3 mo and reached a maximum by 5 mo of age, whereas mean diameter of seminiferous tubules was greater $(\mathrm{P}<0.01)$ at 7 than at 4 or 5 mo of age (Fig. 1).

Testicular volume calculated from ultrasonographic estimates of diameter and length was correlated $(\mathrm{P}<$ 0.001 ) with testicular weight at 4 to 7 mo of age (Table 2). Testicular dimensions were not taken at 3 mo of age, whereas at $10 \mathrm{mo}$, testicular length was beyond the limits of the instrument. The correlation coefficients of mean diameter of seminiferous tubules with testicular weight and with testicular diameter decreased with advancing age becoming nonsignificant at 6 mo for testicular diameter and at 7 mo for testicular weight (Table 2). The coefficient of variation (CV) for mean diameter of seminiferous tubules within each age group of boars, an assessment of variation in pubertal development, decreased from $21.6 \%$ at 3 mo and $20.6 \%$ at 4 mo to $11.2,10.9$, and $6.6 \%$ at 5,6 , and 7 mo of age, respec-

Table 1

Mean ( \pm SEM) body weights at defined stages of development of boars born in different seasons.

\begin{tabular}{|c|c|c|c|c|c|}
\hline \multirow[t]{2}{*}{ Season (Farrowing) } & \multirow[t]{2}{*}{ No. } & \multicolumn{4}{|c|}{ Weight (kg) } \\
\hline & & Birth & Weaning & $2 \mathrm{mo}$ & $5.5 \mathrm{mo}$ \\
\hline 1 (May) & 33 & $1.60 \pm 0.05$ & $5.9 \pm 0.15^{\mathrm{a}}$ & $19.9 \pm 0.73$ & $91.0 \pm 2.21^{\mathrm{a}}$ \\
\hline 2 (July) & 69 & $1.65 \pm 0.04$ & $5.4 \pm 0.13^{\mathrm{b}}$ & $21.4 \pm 0.57$ & $99.4 \pm 2.05^{\mathrm{b}}$ \\
\hline 3 (January) & 58 & $1.55 \pm 0.04$ & $5.5 \pm 0.15^{\mathrm{b}}$ & $20.1 \pm 0.53$ & $93.0 \pm 1.93^{\mathrm{a}}$ \\
\hline
\end{tabular}

a,b Within a column, means without a common superscript differ $(\mathrm{P}<0.05)$. 


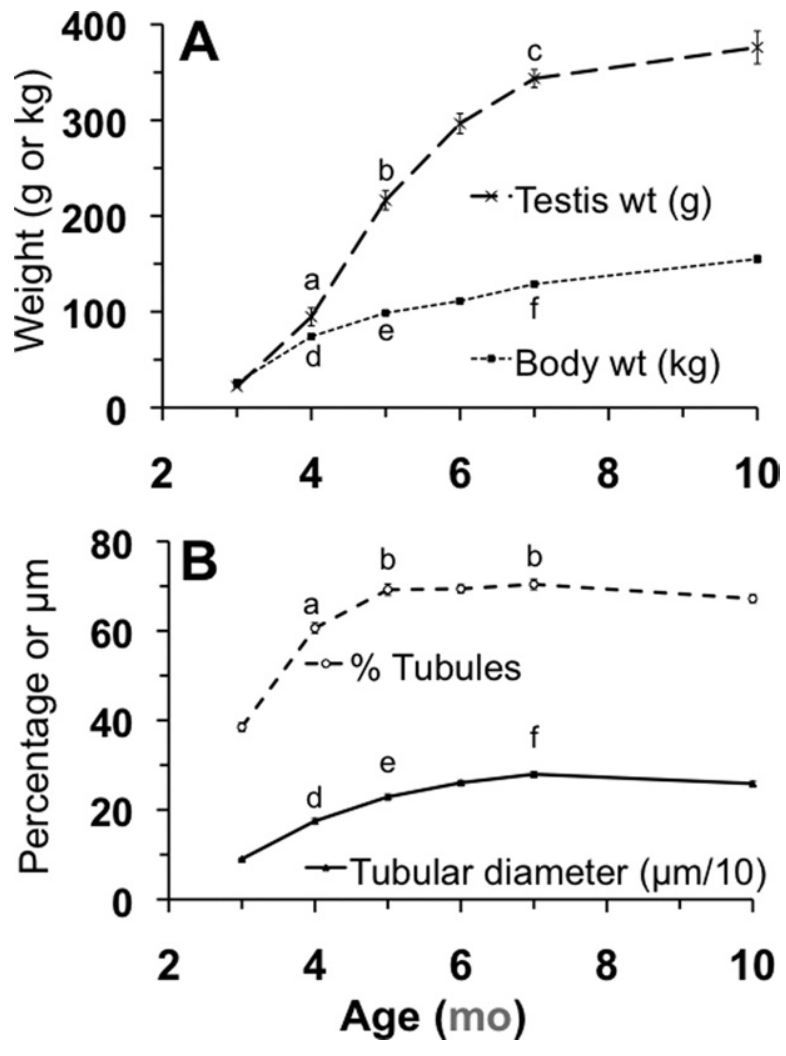

Fig. 1. Developmental changes in testicular trait of boars. (A) Increases in body weight and right testicular weight with age $(\mathrm{P}<$ 0.001). (B) Percentage of the testis occupied with seminiferous tubules and diameter of seminiferous tubules. Diameter was divided by 10 to better fit the data to the scale of the figure. Statistical comparisons were limited to boars that were unilaterally castrated at 4, 5, or 7 mo of age due to their common season of rearing.

${ }^{\mathrm{a}-\mathrm{c}}$ Means without a common superscript differ $(\mathrm{P}<0.01)$.

tively. Similarly, the CV for testicular diameter decreased from $16.1 \%$ at 4 mo to $12.6,8.1$, and $5.6 \%$ at 5,6 , and 7 mo of age, respectively.

Testicular weight at 10 mo of age was $571 \pm 22$, $512 \pm 19,546 \pm 19,498 \pm 17$ and $495 \pm 19 \mathrm{~g}$ (mean \pm
SEM) for boars unilaterally castrated at 3, 4, 5, 6 and 7 mo of age, respectively. For boars unilaterally castrated at 4,5 or 7 mo of age, percentage of seminiferous tubules $(69.5 \pm 1,69.5 \pm 1,71.7 \pm 1 \%$, respectively) and weight of seminiferous tubule $(323 \pm 13,345 \pm$ $13,326 \pm 13 \mathrm{~g}$, respectively) at 10 mo of age were similar $(\mathrm{P}>0.2)$. The correlation coefficients within each boar of weight of the testis removed at hemicastration with weight of the second testis removed at 10 mo of age were low $(\mathrm{r}<0.3)$ for boars hemicastrated at $3,4,5$, or 7 mo of age $(\mathrm{P}>0.10)$. In contrast, this relationship was positive $(\mathrm{r}=0.73)$ for boars that were hemicastrated at 6 mo of age $(\mathrm{P}<0.001)$.

\subsection{Experiment 2}

At $114 \mathrm{~d}$ of age, testicular diameter of conscious boars determined by ultrasonography was $3.2 \pm 0.09$ $\mathrm{cm}$ (range, 2.4 to $4.6 \mathrm{~cm} ; \mathrm{N}=25$ ). The correlation coefficient of the first estimate with the second estimate on the same day was $0.91(\mathrm{P}<0.001)$. Diameter at $134 \mathrm{~d}$ of age was $4.7 \pm 0.11 \mathrm{~cm}$ (range, 3.5 to $5.8 \mathrm{~cm}$ ), and the within boar correlation of diameter at $114 \mathrm{~d}$ with that at $134 \mathrm{~d}$ was $0.85(\mathrm{P}<0.001)$. Mean total testicular weight at 10 mo of age was $740 \pm 0.3 \mathrm{~g}$; the correlations of diameter at 114 or $134 \mathrm{~d}$ of age with total testicular weight at 10 mo were 0.2 and 0.17 , respectively $(\mathrm{P}>0.5)$.

\subsection{Experiment 3}

At $96 \mathrm{~d}$ of age, the correlation of the testicular diameter, determined by ultrasonography of conscious boars, of left testis with that of the right testis was 0.87 $(\mathrm{P}<0.001)$. Within boar correlations of left testis diameter at successively older ages were significant for these 63 boars; however, the magnitude of the correlations was reduced as the number of days between evaluations increased (Table 3). Mean testicular diameter was $2.8 \pm 0.06,4.1 \pm 0.12,5.1 \pm 0.12$, and $6.2 \pm 0.11$

Table 2

Within-boar correlation coefficients (r) of testicular traits at specified ages.

\begin{tabular}{ccccccc}
\hline Age (mo) & No. & $\begin{array}{c}\text { Volume versus } \\
\text { testis weight }\end{array}$ & $\mathrm{P}$ & $\begin{array}{c}\text { Testis weight versus } \\
\text { tubular diameter }\end{array}$ & $\mathrm{P}$ & $\begin{array}{c}\text { Testis diameter versus } \\
\text { tubular diameter }\end{array}$ \\
\hline 3 & 24 & & & 0.79 & 0.001 & \\
4 & 24 & 0.95 & 0.001 & 0.63 & 0.001 & 0.71 \\
5 & 21 & 0.93 & 0.001 & 0.66 & 0.001 & 0.75 \\
6 & 33 & 0.85 & 0.001 & 0.35 & 0.025 & 0.15 \\
7 & 24 & 0.78 & 0.001 & 0.10 & 0.27 & 0.001 \\
10 & 34 & & & 0.09 & 0.27 & 0.48 \\
\hline
\end{tabular}

${ }^{\text {a }}$ Prolate sphere; volume, $4 / 3 \pi^{*}($ length $/ 2) *(\text { width } / 2)^{2}$. 
Table 3

Within-boar correlation coefficients (r) of testis diameters at specified ages. $^{\text {a }}$

\begin{tabular}{cccc}
\hline Age (d) & $122 \pm 0.3$ & $144 \pm 0.3$ & $164 \pm 0.3$ \\
\hline $96 \pm 0.4$ & 0.78 & 0.73 & 0.56 \\
122 & - & 0.87 & 0.66 \\
144 & - & - & 0.83 \\
\hline
\end{tabular}

${ }^{\mathrm{a}}(\mathrm{P}<0.001)$ for all correlations.

$\mathrm{cm}$ at mean ages of $96,122,144$, and $164 \mathrm{~d}$, respectively.

\section{Discussion}

The current studies established that, within groups of boars of similar chronological age from 3 to $5 \mathrm{mo}$, stage of pubertal development as defined by mean diameter of seminiferous tubules, was highly correlated with testicular weight and testicular diameter determined by ultrasonography. The CV of mean seminiferous tubule diameter within age groups decreased from 3 to $7 \mathrm{mo}$, indicative of less variation in testicular development as boars progressed through the pubertal process. Likewise, the decrease in the $\mathrm{CV}$ for testicular diameter decreased with age reflecting the significant correlation of seminiferous tubule diameter with testicular diameter in pubertal boars. These findings supported use of ultrasonographic determination of testicular diameter at a defined early age of pubertal development as a means to rank boars of similar chronological age for extent of pubertal development (if selection for this trait had merit).

Harder et al [16] reporteded that boars from a line selected for large testes at 5 mo of age also had more rapid pubertal development of their testes than boars of the randomly selected control line. However, these correlated responses to selection should not be accepted as evidence that early puberty establishes large testicular size at maturity. Meishan and Piau are breeds of boars that have small testicular size as adults, relative to breeds commonly used in commercial swine production. However, Meishan boars undergo pubertal testicular development at a much younger age than Piau boars. Growth of seminiferous tubules to a mean diameter of $100 \mu \mathrm{m}$ occurs before $50 \mathrm{~d}$ of age in Meishan boars [17-19], but the seminiferous tubules of Piau boars do not achieve this diameter until after $120 \mathrm{~d}$ of age [20,21], and the size of postpubertal testes of Piau boars is greater than in Meishan boars. Furthermore, our second study provided no support for a correlation of testicular diameter early in pubertal development with testicular size of adult boars. Likewise, in the first study in which boars were unilaterally castrated at 4,5 , or $7 \mathrm{mo}$ of age, the weight of the first testis was not associated with the weight of the remaining testis at 10 mo. Based on these observations, early onset of pubertal development, relative to later pubertal development, will not be associated with greater sperm production of adult boars in all genetic lines.

The blood-testis barrier is formed by 4 mo of age in commercial breeds of boars; therefore, a compensatory increase in number of Sertoli cells should not occur after unilateral castration at this age or older [19,22]. As a consequence, unilateral castration at 4 mo or later should not modify the genetic potential for testicular growth of individual boars. This was supported by the similar seminiferous tubular weight observed at 10 mo for boars unilaterally castrated at 4,5 or 7 mo. In contrast, unilateral castration a $7 \mathrm{~d}$ of age would produce a compensatory increase in number of Sertoli cells, and this is reflected by greater mass of seminiferous tubules $(384 \pm 15 \mathrm{~g}$; unpublished data from [19]). The significant correlation of testicular weight of boars unilaterally castrated at 6 mo of age with weight of the testis present at 10 mo cannot be explained; however, these boars were from a more uniform population than the boars that were evaluated at the other ages. They were the larger boars from large litters, rather than randomly selected boars as was the situation for boars unilaterally castrated at 4, 5, or 7 mo of age. Rate of sexual development and testicular size were correlated traits in the group of boars that was unilaterally castrated at $6 \mathrm{mo}$, as was the case with the population of boars at the University of Nebraska that was selected for testicular size [16].

The four-breed composite line of boars that was evaluated in the current studies had growth of seminiferous tubules to $100 \mu \mathrm{m}$ at approximately $90 \mathrm{~d}$ of age (Fig. 1) [19] compared with approximately $110 \mathrm{~d}$ of age for Landrace $\times$ Yorkshire boars [23] and Landrace $\times$ Duroc boars [24] and at sometime after $120 \mathrm{~d}$ of age in Hampshire $\times$ Duroc $\times$ Yorkshire boars [25]. Between 3 and 4 mo of age, diameter of seminiferous tubules increased rapidly to $175 \mu \mathrm{m}$ and the tubular composition of the testis increased from 38 to $61 \%$. Also within these ages, the $\mathrm{CV}$ for tubular diameter was the greatest indicating maximum variation in pubertal development. After $4 \mathrm{mo}$, the CV decreased, but the correlation of testicular diameter, determined by ultrasonography, with seminiferous tubule diameter remained significant at $5 \mathrm{mo}$ of age. Consequently, determination of testicular diameter from 3 to 5 mo of age would provide a 
method to rank boars of this genetic line relative to their stage of pubertal development.

Based on the current studies, we infer that boars can be selected for either early or late testicular development without compromising testicular size when appropriate technology is used to estimate testicular size of adult boars. It is well established that daily sperm production of adult boars increases with testicular weight [26-28]. Consequently, there is economic value in producing boars with larger testes for artificial insemination studs. Furthermore, sperm production is moderately heritable [29-31]. In order to predict testicular volume, technology is required to economically estimate both width and length of testes of late pubertal boars (i.e., an age when testicular size correlates with the size of adult testes). A proposed protocol would rank boars for testicular diameter at $\sim 4$ mo of age, a period of greatest variation in diameter of seminiferous tubules. Then boars would be ranked a second time for testicular volume after 8 mo of age. At both evaluations, testicular traits would be adjusted for age and weight of the boar within a defined genetic line.

\section{Acknowledgments}

We thank swine operations personnel for their dedicated service for the care of animals and assistance with tissue collection, G. Rupp of the Great Plain Veterinary Educational Center, University of Nebraska, for use of the Aloka Model SSD-900V, A. Kruger and M. Judy for superb technical support, and L. Parnell for excellent assistance with manuscript preparation.

\section{References}

[1] Gondos B, Berndston WE. Postnatal and pubertal development. In: Russell LD, Griswold MD, editors. The Sertoli Cell. Clearwater, FL: Cache River Press; 1993, p. 115-54.

[2] Franca LR, Avelar GF, Almeida FFL. Spermatogenesis and sperm transit through the epididymis in mammals with emphasis on pigs. Theriogenology 2005;63:300-18.

[3] Lunstra DD, Ford JJ, Echternkamp SE. Puberty in beef bulls: hormone concentrations, growth, testicular development, sperm production and sexual aggressiveness in bulls of different breeds. J Anim Sci 1978;46:1054-62.

[4] Lucas JR, Notter DR, McClaugherty FS, Anderson GW, Gwazdauskas FC. Breed differences in testicular growth and gonadotropin secretion in prepubertal ram lambs. Theriogenology 1983;19:749-58.

[5] Echternkamp SE, Lunstra DD. Relationship between LH and testicular development in progesterone-implanted prepubertal ram lambs. J Anim Sci 1984;59:441-53.

[6] Rawlings N, Evans ACO, Chandolia RK, Bagu ET. Sexual maturation in the bull. Reprod Domest Anim 2008; 43(Suppl 2):295-301.
[7] Cartee RE, Powe TA, Gray BW, Hudson RS, Kuhlers DL. Ultrasonographic evaluation of normal boar testicles. Am J Vet Res 1986;47:2543-8.

[8] Clark SG, Schaeffer DJ, Althouse GC. B-mode ultrasonographic evaluation of paired testicular diameter of mature boars in relation to average total sperm numbers. Theriogenology 2003;60:1011-23.

[9] Holl JW, Rohrer GA, Shackelford SD, Wheeler TL, Koohmaraie $M$. Estimates of genetic parameters for kyphosis in two crossbred swine populations. J Anim Sci 2008;86:1765-9.

[10] FASS. Guide for the Care and Use of Agricultural Animals in Agricultural Research and Teaching, 1st rev. ed., Savoy, IL: Federation of Animal Science Societies; 1999. 120 pp.

[11] McCoard SA, Lunstra DD, Wise TH, Ford JJ. Specific staining of Sertoli cell nuclei and evaluation of Sertoli cell number and proliferative activity in Meishan and White composite boars during the neonatal period. Biol Reprod 2001;64:689-95.

[12] Lunstra DD, Wise TH, Ford JJ. Sertoli cells in the boar testis: changes during development and compensatory hypertrophy after hemicastration at different ages. Biol Reprod 2003;68:140-50.

[13] Okwun OE, Igboeli G, Lunstra DD, Ford JJ, Johnson L. Testicular composition, number of A spermatogonia, germ cell ratios and number of spermatids in three different breeds of boars. J Androl 1996;17:301-9.

[14] Littell RC, Milliken GA, Stroup WW,Wolfinger RD. SAS® System for Mixed Models, Cary, NC: Statistical Analysis System Institute Inc; 1996. 633 pp.

[15] SAS, 1999. SAS/STAT User's Guide. Version 6, vol. 2., 4th ed. Statistical Analysis System Institute Inc, Cary, NC.

[16] Harder RR, Lunstra DD, Johnson RK. Growth of testes and testicular morphology after eight generations of selection for increased predicted weight of testes at 150 days of age in boars. J Anim Sci 1995;73:2186-92.

[17] Lunstra DD, Ford JJ, Klindt J, Wise TH. Physiology of the Meishan boar. J Reprod Fertil Suppl 1997;52:181-93.

[18] Kanematsu N, Jin WZ, Watanabe G, Tays K. Age-related changes of reproductive hormones in young Meishan boars. J Reprod Dev 2006;52:651-6.

[19] Ford JJ, Wise TH. Sertoli cell differentiation in pubertal boars. J Anim Sci 2009;87:2536-43.

[20] Castro ACS, Cardoso FM, Franca LR. Effect of puberty and sexual development on daily sperm production and epididymal sperm reserves of Piau boars. Anim Reprod Sci 1991;25:83-90.

[21] Franca LR, Silva VA Jr, Chiarini-Garcia H, Garcia SK, Debeljuk L. Cell proliferation and hormonal changes during postnatal development of the testis in the pig. Biol Reprod 2000; 63:1629-36.

[22] Tran D, Meusy-Dessolle N, Josso N. Waning of anti-Mullerian activity: An early sign of Sertoli cell maturation in the developing pig. Biol Reprod 1981;24:923-31.

[23] van Straaten HWM, Wensing CJG. Histomorphic aspects of testicular morphogenesis in the pig. Biol Reprod 1977;17:467-72.

[24] Allrich RD, Christenson RK, Ford JJ, Zimmerman DR. Pubertal development of the boar: age related changes in testicular morphology and in vitro production of testosterone and estradiol17b. Biol Reprod 1983;28:902-8.

[25] Lee K-H, Diekman MA, Moss GE, Allrich RD. Pituitary gonadotropins, hypothalamic gonadotropin-releasing hormone, and testicular traits of boars exposed to natural or supplemental lighting during pubertal development. Biol Reprod 1987;36: 1164-9. 
[26] Hemsworth PH, Winfield CG, Hansen C. High mating frequency of boars: the effect on sexual behaviour, fertility and fecundity. Anim Prod 1983;37:409-13.

[27] Huang Y-T, Johnson RK. Effect of selection for size of testes in boars on semen and testis traits. J Anim Sci 1996;74:750-60.

[28] Ford JJ, Wise TH, Lunstra DD, Rohrer GA. Interrelationships of porcine $\mathrm{X}$ and $\mathrm{Y}$ chromosomes with pituitary gonadotropins and testicular size. Biol Reprod 2001;65:906-12.
[29] Smital J,Wolf J, De Sousa LL. Estimation of genetic parameters of semen characteristics and reproductive traits in AI boars. Anim Reprod Sci 2005;86:119-30.

[30] Oh SH, See MT, Long TE, Galvin JM. Genetic parameters for various random regression models to describe total sperm cells. J Anim Sci 2006;84:538-45.

[31] Flowers WL. Genetic and phenotypic variation in reproductive traits of AI boars. Theriogenology 2008;70:1297-303. 